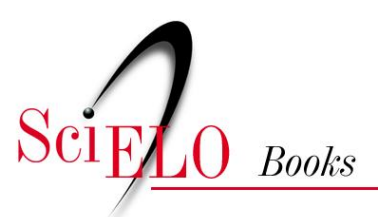

\title{
Ordem Lampriformes
}

\author{
Ana Cristina Teixeira Bonecker \\ Claudia Akemi Pereira Namiki \\ Márcia Salustiano de Castro \\ Paula Nepomuceno Campos
}

\section{SciELO Books / SciELO Livros / SciELO Libros}

BONECKER, ACT., et al. Ordem Lampriformes. In Catalogo dos estágios iniciais de desenvolvimento dos peixes da bacia de Campos [online]. Curitiba: Sociedade Brasileira de Zoologia, 2014, pp. 128-130. Zoologia: guias e manuais de identificação series. ISBN 978-85-98203-10-2.

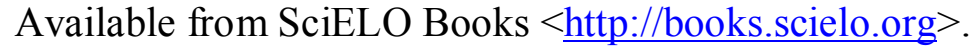

\section{(2)(1)(2)}

All the contents of this chapter, except where otherwise noted, is licensed under a Creative Commons Attribution-Non Commercial-ShareAlike 3.0 Unported.

Todo o conteúdo deste capítulo, exceto quando houver ressalva, é publicado sob a licença Creative Commons Atribuição Uso Não Comercial - Partilha nos Mesmos Termos 3.0 Não adaptada.

Todo el contenido de este capítulo, excepto donde se indique lo contrario, está bajo licencia de la licencia Creative Commons Reconocimento-NoComercial-CompartirIgual 3.0 Unported. 


\section{ORDEM LAMPRIFORMES}

A ordem Lampriformes é composta por sete famílias com aproximadamente 21 espécies. Os peixes desta ordem apresentam maxila superior protrátil, não possuem espinhos verdadeiros nas nadadeiras e as pélvicas possuem de 0-17 raios.

Nesse estudo a ordem Lampriformes é representada pela família Trachipteridae. 


\section{Família Trachipteridae}

A família Trachipteridae é mesopelágica e ocorre em todos os oceanos. Compreende três gêneros com aproximadamente dez espécies. Possuem corpo alongado e lateralmente comprimido. As maxilas são muito protráteis. Não possuem nadadeira anal. As nadadeiras dorsal e caudal são muito longas. A nadadeira pélvica é rudimentar nos adultos de algumas espécies, mas muito conspícua nas larvas. As larvas apresentam os primeiros raios da nadadeira dorsal e os raios da nadadeira pélvica longos e ornamentados.

No Brasil já foram identificadas três espécies nas fases de larva e adulto: Desmodema polystictum (Ogilby, 1879); Trachipterus jacksonensis (Ramsay, 1881) e Zu cristatus (Bonelli, 1819). Na área de estudo é contemplada a espécie Zu cristatus. 


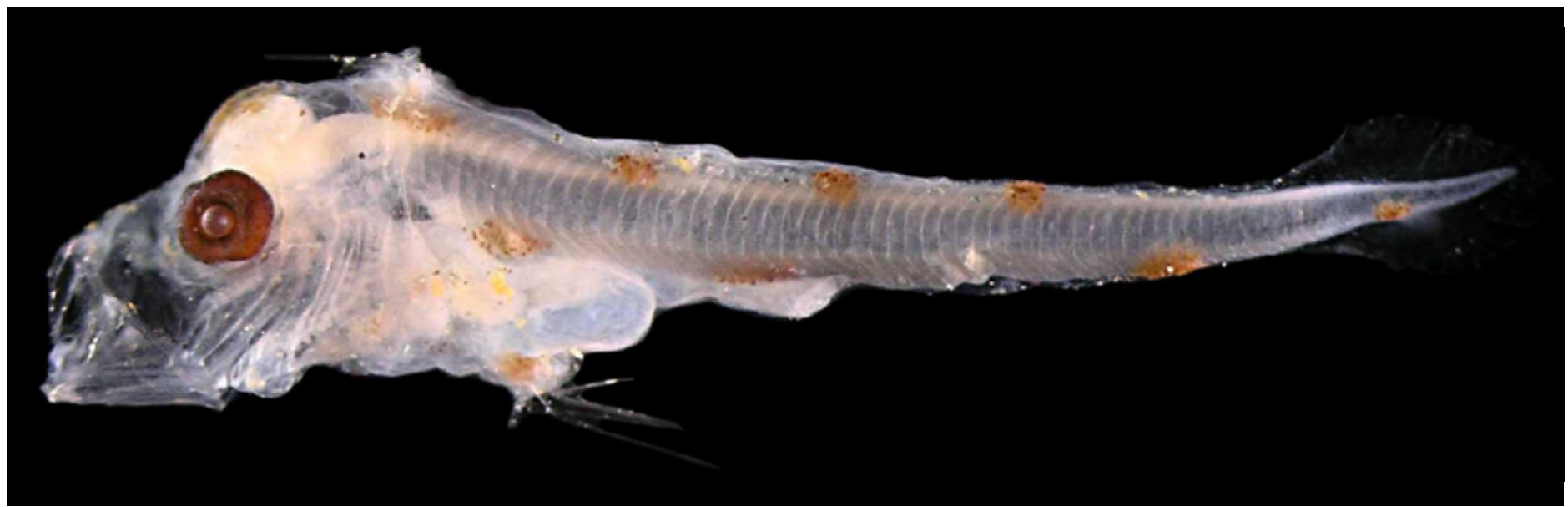

Figura 79: Zu cristatus. DZUFRJ 22487; Pré-flexão; CP 6,0 mm.

\section{Zu cristatus \\ (Bonelli, 1819)}

Desenvolvimento precoce dos primeiros raios das nadadeiras dorsal e pélvica. Não tem nadadeira anal. Série de pigmentos alternados nas margens dorsal e ventral do corpo. Pigmentos espalhados na região do crânio. Mandíbula protrátil. O número de miômeros varia aproximadamente entre 62 e 69.

Tamanho: pré-flexão 6,0 mm.

Habitat: espécie marinha, epi-mesopelágica, ocorre em águas tropicais e temperadas até $90 \mathrm{~m}$ de profundidade.

\section{Georreferenciamento}

\begin{tabular}{|c|c|c|c|c|c|c|c|c|}
\hline DZUFRJ & Latitude (S) & Longitude (W) & Data & $\begin{array}{c}\text { Tipo de } \\
\text { arrasto }\end{array}$ & $\begin{array}{c}\text { Profundidade } \\
\text { de coleta }\end{array}$ & Rede & $\begin{array}{c}\text { Malha } \\
(\boldsymbol{\mu m})\end{array}$ & $\begin{array}{c}\mathbf{N}^{\circ} \text {. de } \\
\text { inds. }\end{array}$ \\
\hline 22487 & $21^{\circ} 58^{\prime} 31,0^{\prime \prime}$ & $039^{\circ} 50^{\prime} 29,7^{\prime \prime}$ & $10 / 10 / 2001$ & oblíquo & $1.000 \mathrm{~m}$ & cilíndrico-cônica & 500 & 1 \\
\hline
\end{tabular}

Referências: Olney, 2006a; Fahay, 2007. 